\title{
Validity of Interactive Multimedia with 3D Visualization to Practice the Spatial Visual Intelligence of Class X High School Students on Metallic Bonding Materials
}

\author{
Irvandar Nurviandy \\ Department of Chemistry \\ Universitas Negeri Surabaya \\ Surabaya, Indonesia \\ Ahlan Riwahyu Habibi \\ Department of Chemistry \\ Universitas Negeri Surabaya \\ Surabaya, Indonesia
}

\author{
Kusumawati Dwiningsih* \\ Department of Chemistry \\ Universitas Negeri Surabaya \\ Surabaya, Indonesia \\ kusumawatidwiningsih@unesa.ac.id \\ Achmad Fitriadi Akbar \\ Department of Chemistry \\ Universitas Negeri Surabaya \\ Surabaya, Indonesia
}

This study aims to determine the validity of Interactive Multimedia with 3D Visualization to Train the Spatial Visual Intelligence of Class $X$ High School Students on Metallic Bonding Materials. Validity is tested through quality of content and goals, instructional quality, and technical quality. Development is carried out using the ADDIE model (Analysis, Design, Development or Production, Implementation or Delivery and Evaluations). This research is limited only in 3 stages, namely Analysis, Design, and Development. Interactive multimedia is said to be valid if the minimum achievement level scores in the range 61-80 with good qualifications based on the eligibility criteria and product revisions which are adaptations of Siti Muriati, 2013. Based on the analysis that has been done, it is found that interactive multimedia with 3D visualization developed is stated valid with an average percentage of content validation by material experts that is $96 \%$ and construct validation by material experts that is $91.82 \%$ are in the feasible category with a very good predicate. Thus, the results of this study indicate that interactive multimedia with 3D visualization on metal bonding material can be declared valid.

Keywords - 3D interactive multimedia, spatial visuals, metal bonds.

\section{INTRODUCTION}

The subject of chemistry is considered as one of the difficult subjects because many concepts of chemistry cannot be actualized, but only through schematic modeling. Modeling or abstraction requires the visual spatial ability of students in supporting the learning process [1][2]. In addition, the skills and creativity of teachers in delivering material are also needed [3].

One of the subjects which is an obstacle for students is chemical bonds. Based on data on the value of the National Examination in 2017, the percentage of students' material authority in the chemical bond material covering ion, covalent and metal bonds in East Java province was $41.67 \%$, while the national data with a percentage of $44.44 \%$. In 2018 , with the same material coverage, the percentage of students in mastering the material was $52.38 \%$ at the provincial level (East Java) and $51.98 \%$ at the national level. This value indicates that there are more than $45 \%$ of students who have not mastered the chemical bonding material as a whole.

The 21st century is also known as the age of knowledge (knowledge age), in this era, all alternative efforts to meet the needs of life in various contexts are more knowledge based [3][4]. Efforts to meet the needs of the field of knowledgebased education, the development of a knowledge-based economy, the development and empowerment of knowledgebased social empowering, and the development in the field of industry-based knowledge [5][6].

Indonesia has an Information and Communication Technology Development Index (IP-ICT) which increased from 2015 to 2017, the Indonesian IP-TIK in 2015 amounted to 3.88 , then in 2016 an increase of 4.34 , and also in 2017 increase to 4.99 [7]. This means that the level of technological literacy in Indonesian society is fairly good. This is supported by the very high level of Internet users in Indonesia, which ranks 6th in the World or data users around 123 million people [8].

Metal bonding is a chemical that discusses how bonds between metals can occur, in terms of the concept of a sea of electrons. Where the metal consists of positive ions with electrons scattered around and moving freely [9] [10]. In its teaching, metal bonding material, especially regarding the concept of oceanic electrons requires three-dimensional modeling to facilitate how metal bonds can be formed and the peculiarities they have compared to ionic, covalent, and covalent bonds of coordination [11][12][13]. In order to compensate for the situation, one aspect that needs to be improved is in the optimal use of information and communication technology (ICT) for the purposes of learning chemistry, especially chemical bonding material [14][15]. The use of ICT such as interactive multimedia can affect student learning abilities, one example of its 
application is through blended learning that improves student learning outcomes in the medium and high categories, and the development of virtual lab-based media that gets a percentage of validity $\geq 61$ [16][17]. One of the subjects in chemical bonds is about metal bonds, the learning methods taught are often focused on memorizing concepts or visual spatial [18][19].

Through the development of interactive multimedia with $3 \mathrm{D}$ visualization, the writer wants to make it easier for students to understand the concept of metal bonds and practice the students' visual spatial abilities. Development is carried out using the ADDIE model (Analysis, Design, Development or Production, Implementation or Delivery and Evaluations) [20]. Multimedia will be applied, packaged into an interactive multimedia, where students can learn while moving 3D modeling animations from metal bonds. Multimedia is equipped with three-dimensional visualization, explanation and problems related to metal bonds. Multimedia is also equipped with two languages namely Indonesian and English.

\section{METHOD}

\section{A. Research design}

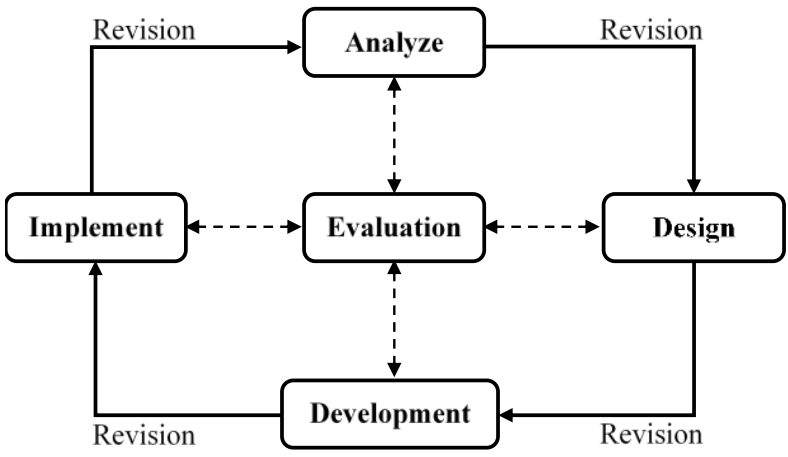

Fig 1. ADDIE Model

The study uses a research model adapted from the ADDIE development model (Analysis, Design, Develop, Implement, and Evaluation) [21]. This model uses 5 stages, namely Analysis, Design, Development, Implementation, and Evaluation stages. However, in this research development there are only 3 stages: Analysis, Design, and Development.

\section{B. Research Settings}

Validation is carried out for the content and construct aspects. Content validation is carried out by one chemistry lecturer who is an expert in metal bonding or inorganic chemistry. The construct validation was carried out by one lecturer who was an expert in the development of IT-based learning media.

\section{Product Assessment and Data Analysis}

Through the content validity sheet instrument which was assessed by the material expert, the interactive multimedia that was developed was validated by the material expert which are the lecturer who was an expert in the subject of metal bonding. The aspects assessed are quality of content and objectives, instructional quality, and technical quality. Then through the construct validity sheet instrument, interactive multimedia that was developed was validated by media experts. Media experts will provide an assessment of the aspects of interactive multimedia display and programming.

Data collection techniques used are quantitative descriptive data analysis, used to process data from the results of expert validation of the material, design, and learning media in the form of input suggestions and criticisms of improvements contained in the validation instrument questionnaire and qualitative descriptive statistical analysis used to analyze the data obtained in the form of percentage analysis.

$$
\text { Validity }(\%)=\frac{\text { Eoverall score }}{\text { Eeriteria score }} \times 100 \%
$$

$\Sigma$ criteria score $=$ highest score per item $\times$ number of validator.

\section{TABLE I. PRODUCT ELIGIBILITY AND REVISION CRITERIA}

\begin{tabular}{|c|c|c|}
\hline $\begin{array}{c}\text { Level of } \\
\text { achievement }\end{array}$ & Qualification & Information \\
\hline $81-100$ & Very Good & Valid/no revision \\
\hline $61-80$ & Good & Valid/no revision \\
\hline $41-60$ & Enough & Not valid/revision \\
\hline $21-40$ & Less & Not valid/revision \\
\hline $0-20$ & Not Enough & Not valid/revision \\
\hline
\end{tabular}

Adaptation from Siti Muriati, 2013 [22]

\section{Product Assessment and Data Analysis}

Analysis is done to estimate whether all aspects of learning involved in it are in accordance with capacity. Data analysis was carried out namely: collecting all data from observations in the form of quantitative data; analyze data by tabulating percentages presented in tables and graphs; and test the success of research by means of quantitative data analysis which is then matched to the eligibility criteria and product revisions [22].

\section{E. Indicator of Success}

Interactive multimedia is said to be valid if the minimum level of achievement scores in the range 61-80 with good qualifications based on the eligibility criteria and product revisions which are adaptations of Siti Muriati, 2013 [22].

\section{RESULTS AND DISCUSSION}

\section{A. Validity of $3 D$ Interactive Multimedia}

Validation aims to determine the validity of interactive multimedia that was developed based on the results of the assessment provided by 2 validators, namely two chemistry lecturers. There are two aspects that are validated including content and construct validity. Before being validated, 3D interactive multimedia developed was first reviewed by one chemistry lecturer. 
The application development process begins with the stages of analyze conducted by the developer to collect the data needed in the development of interactive multimediabased learning media including: the competency standards of chemical bond material; metal bonding sub-material; problems arising in the study of chemistry with the topic of metal bonding; analysis of students and carrying capacity of the use of instructional media. Followed by the planning or design phase, at this stage the development of media is formulated based on data obtained from the analysis phase. There are several things done by researchers, namely: Determining the standard of competence in the material of chemical bonds sub-material of metal bonds and the purpose of making learning media to fit the 2013 curriculum; determine the basic competencies of the metal bond submaterial; make a flowchart; and make a storyboard.

The next stage is development, In the development stage there are 3 activities: Product making; validation; and revision.

The design and features contained in interactive multimedia consist of 1 main page (homepage) and 5 additional pages, consisting of Competences, introductory, material, quiz, and author profiles pages. Background design uses Adobe Photoshop CS6 and Adobe Illustrator CC 2017 application, meanwhile for the overall design and programming application uses Aurora 3D Presentation 2012.

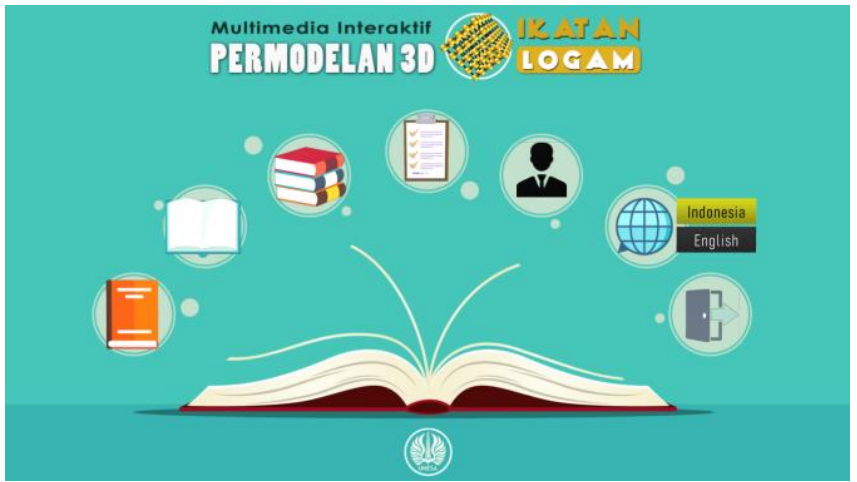

Fig 2. Homepage Layout

The main page design consists of a background designed with Adobe Photoshop CS6 and Adobe Illustrator CC 2017. In the middle there are 7 clickable icons, 5 of 7 icons are hyperlinks to other pages, 1 icon to change language (two language options are available, namely Indonesian and English), and finally the exit button.

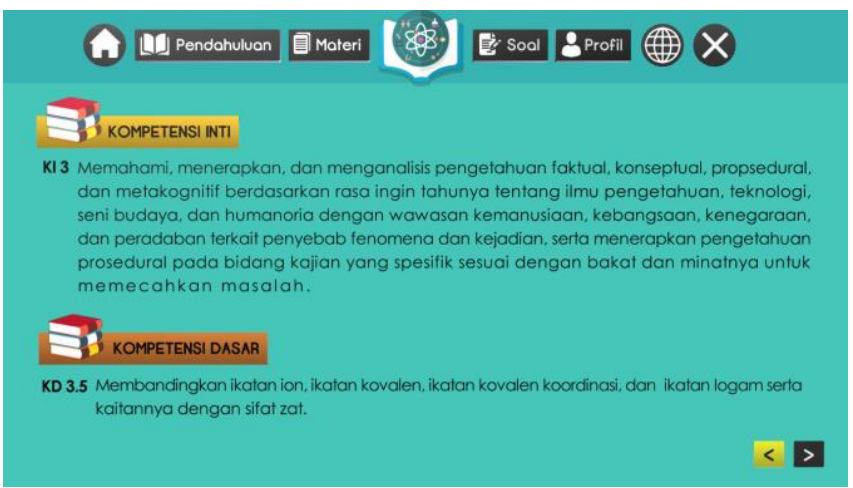

Fig 3. Competences Page
Competences page consist of core competence and basic competence used in metallic bonding matters adapted to the latest 2013 revised curriculum.

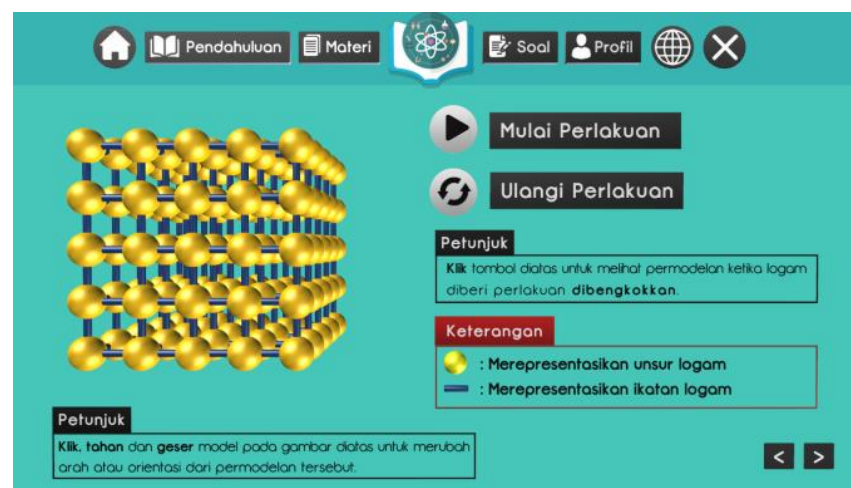

Fig 4. Material / Matters Pages

The material page consists of flash animated videos, description of material, images and interactive videos that can be played, paused and repeated. The main part of this page is the visualization of metal bonding material in 3D that can be rotated in all directions to facilitate the visualization of students about the material.

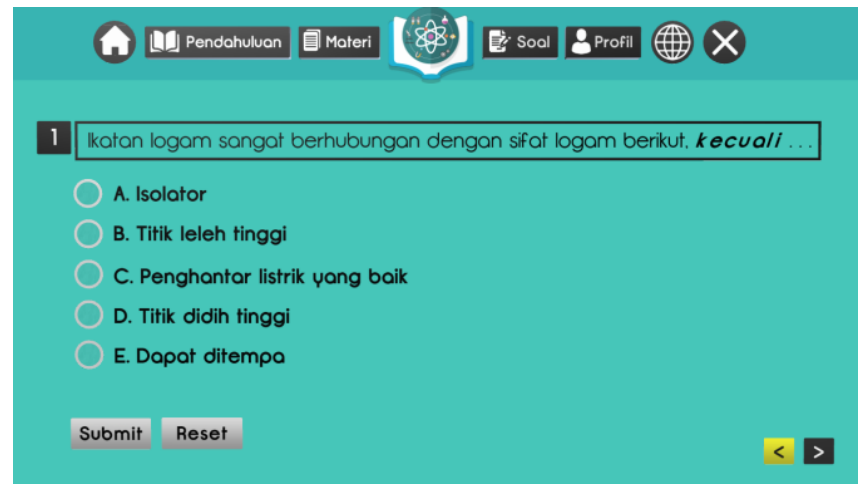

Fig 5. Quiz Pages

The quiz page is designed with multiple choice questions where the user is asked to choose one of the options and if you are sure you can lock the answer then click the "submit" button.

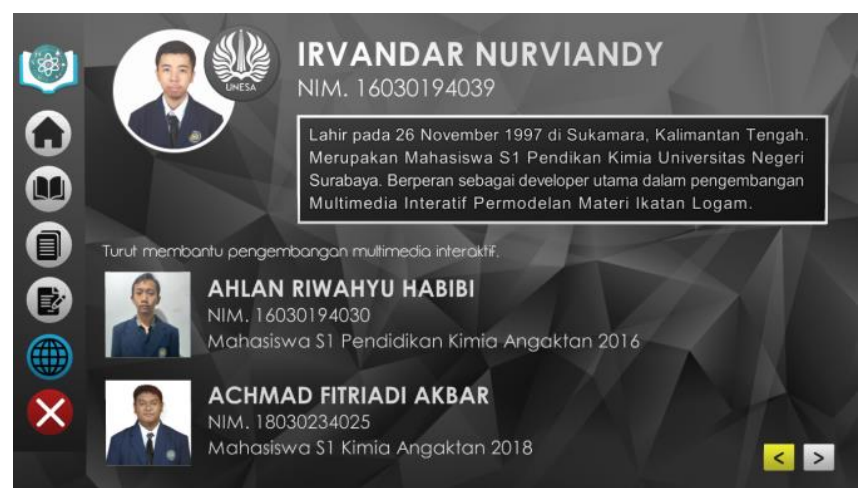

Fig 6. Author Profiles

The author profile page contains a short biography of the person who played a role in developing 3D interactive multimedia on this metallic bonding material. Consists of 1 programmer and main designer, one assistant designer and one person who designs content. 
Through content validity (including linguistic, content standards, and learning, with the total of 15 criteria items) instruments validated by material experts and construct validity (including: linguistic, content standards, and learning, with the total of 22 criteria items) instruments validated by media experts. Analyzed using calculations based on:

$$
\text { Validity }(\%)=\frac{\text { Eoverall score }}{\text { Eeriteria score }} x 100 \%
$$

$\Sigma$ criteria score $=$ highest score per item $\times$ number of validator.

With criteria:

TABLE II. PRODUCT ELIGIBILITY AND REVISION CRITERIA

\begin{tabular}{|c|c|c|}
\hline $\begin{array}{c}\text { Level of } \\
\text { achievement }\end{array}$ & Qulaification & Information \\
\hline $81-100$ & Very Good & Valid/no revision \\
\hline $61-80$ & Good & Valid/no revision \\
\hline $41-60$ & Enough & Not valid/revision \\
\hline $21-40$ & Less & Not valid/revision \\
\hline $0-20$ & Not Enough & Not valid/revision \\
\hline
\end{tabular}

Adaptation from Siti Muriati, 2013 [22]

The results show that the average percentage of content validation by material experts, namely $96 \%$, is in the feasible category with a very good predicate. Likewise, with the construct validity, the results show that the construct validity by media experts is $91.82 \%$, is in the feasible category with a very good predicate. However, it still needs to be revised for further improvement. The revision of the content of the material is also based on suggestions and input from the material expert validator mentioned in the data presentation section, as well as verbal advice during discussions with the material experts.

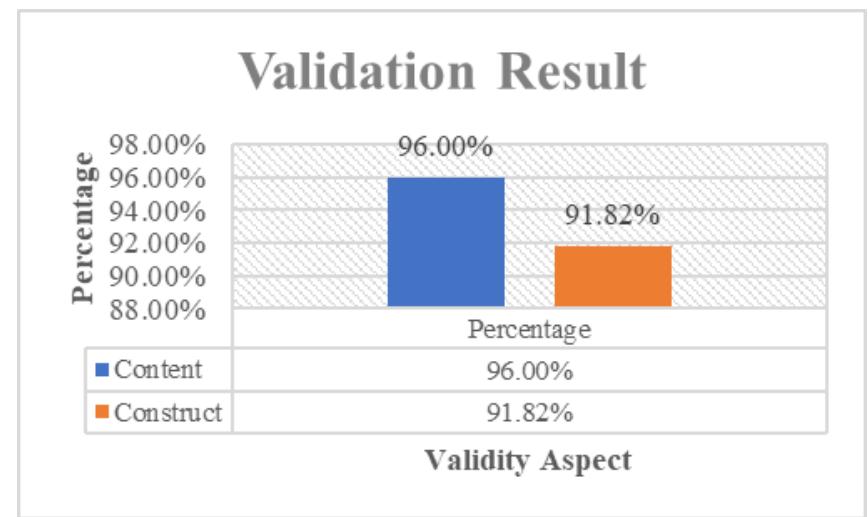

Fig 7. Validation Result

\section{CONCLUSION}

Based on the analysis that has been done, the results show that interactive multimedia with $3 \mathrm{D}$ visualization developed is declared valid with an average percentage of content validation by material experts that is $96 \%$ and construct validation by material experts that is $91.82 \%$ are in the feasible category with excellent predicate. So that this 3D Interactive Media classified as valid.

\section{ACKNOWLEDGMENT}

For more details, we will discuss further in a seminar later on October 5, 2019, State University of Surabaya.

\section{REFERENCES}

[1] T. L. (Theodore L. Brown and T. L. (Theodore L. Brown, Chemistry: the central science. Prentice Hall, 2002.

[2] M. Robert and E. Chevrier, "Does men's advantage in mental rotation persist when real three-dimensional objects are either felt or seen?," Mem. Cogn., vol. 31, no. 7, pp. 1136-1145, 2003.

[3] E. Y. Wijaya, D. A. Sudjimat, and A. Nyoto, "Transformasi Pendidikan Abad 21 Sebagai Tuntutan Transformasi Pendidikan Abad 21 Sebagai Tuntutan," in Prosiding Seminar Nasional Pendidikan Matematika 2016, 2016.

[4] O. Kurniawan, "PENERAPAN KURIKULUM 2013 DALAM MENINGKATKAN KETERAMPILAN, SIKAP, DAN PENGETAHUA," vol. 6, pp. 389-396, 2017.

A. Mukhadis, "Sosok Manusia Indonesia Unggul dan Berkarakter dalam Bidang Teknologi sebagai Tuntutan Hidup," J. Pendidik. Karakter, pp. 115-136, 2013.

[6] M. Ollino, J. Aldoney, A. M. Domínguez, and C. Merino, “A new multimedia application for teaching and learning chemical equilibrium," Chem. Educ. Res. Pract., vol. 19, no. 1, pp. 364 374, Jan. 2018.

[7] Badan Pusat Statistik, "Perkembangan Indeks Pembangunan Teknologi Informasi dan Komunikasi (IP-TIK),” no. 102, pp. 1$8,2018$.

[8] W. Hidayat, "Pengguna Internet Indonesia Nomor Enam Dunia," eMarketer.com, 2014. [Online]. Available: https://kominfo.go.id/content/detail/4286/pengguna-internetindonesia-nomor-enam-dunia/0/sorotan_media. [Accessed: 16Oct-2018].

[9] C. E. Housecroft and A. G. Sharpe, Inorganic chemistry. Pearson Prentice Hall, 2008

[10] Effendy, Ikatan Kimia dan Kimia Anorganik. Malang: Bayumedia Publishing, 2004.

[11] G. L. Miessler and D. A. (Donald A. Tarr, Inorganic chemistry, 3rd edition. Pearson Education, 2004.

[12] N. N. (Norman N. Greenwood and A. (Alan) Earnshaw, Chemistry of the elements, 2nd ed. Oxford: ButterworthHeinemann, 1997.

[13] N. G. Connelly, T. Royal Society of Chemistry (Great Britain), R. M. International Union of Pure and Applied Chemistry., and A. T. Hutton, Nomenclature of inorganic chemistry. IUPAC recommendations 2005. Royal Society of Chemistry, 2005.

[14] C. L. Habraken, "Perceptions of chemistry: why is the common perception of chemistry, the most visual of sciences, so distorted?," J. Sci. Educ. Technol., vol. 5, pp. 193-201, 1996.

[15] M. Braund and M. J. (Michael J. Reiss, Learning science outside 
the classroom. RoutledgeFalmer, 2004.

[16] K. Dwiningsih, Nf. Sukarmin, Nf. Muchlis, and P. T. Rahma, "Pengembangan Media Pembelajaran Kimia Menggunakan Media Laboratorium Virtual Berdasarkan Paradigma Pembelajaran Di Era Global," Kwangsan J. Teknol. Pendidik., vol. 6, no. 2, pp. 156-176, 2018.

[17] U. U. Arham and K. Dwiningsih, "Keefektifan Multimedia Interaktif Berbasis Blended Learning Untuk Meningkatkan Hasil Belajar Siswa,” J. Kwangsan, vol. 4, no. 2, p. 111, 2016.

[18] J. L. Kincheloe, Multiple intelligences reconsidered. P. Lang, 2004

[19] S. M. Al-Balushi and S. H. Al-Hajri, "Associating animations with concrete models to enhance students' comprehension of different visual representations in organic chemistry," Chem. Educ. Res. Pr., vol. 15, no. 1, pp. 47-58, Jan. 2014.

[20] E. Kagia and P. A. Harza, "Pengembangan multimedia interaktif menggunakan software aurora $3 \mathrm{~d}$ pada materi senyawa hidrokarbon kelas XI ipa di SMAN 8 kota jambi,” 2017.

[21] E. Mulyatiningsih, Metoode Penelitian Terapan Bidang Pendidikan. Bandung: Alfabeta, 2012.

[22] S. Muriati, "Pengembangan Bahan Ajar Biologi Sel Dengan Model Addie Pada Program Studi Pendidikan Biologi UIN Alauddin Makasar,” Universitas Negeri Malang, 2013. 